Article

\title{
Characteristics of Biogas Production from Organic Wastes Mixed at Optimal Ratios in an Anaerobic Co-Digestion Reactor
}

\author{
Young-Ju Song ${ }^{1}$, Kyung-Su Oh ${ }^{1}$, Beom Lee ${ }^{2}$, Dae-Won Pak ${ }^{1}$, Ji-Hwan Cha ${ }^{3}$ and Jun-Gyu Park ${ }^{4, *}$ (I) \\ 1 Department of Environmental Energy Engineering Graduate School of Convergence Science, Seoul National \\ University of Science and Technology, 232 Gongneung-ro, Nowon-gu, Seoul 01811, Korea; \\ loveoju@nate.com (Y.-J.S.); kyungsu.oh@samsung.com (K.-S.O.); daewon@seoultech.ac.kr (D.-W.P.) \\ 2 Nature Engineering Co., Ltd., E-9, 1 Chungdae-ro, Seowon-gu, Cheongju-si 28644, Chungcheongbuk-do, \\ Korea; lee49871@naver.com \\ 3 Department of Environmental Engineering, Chungbuk National University, Cheongju-si 28644, \\ Chungcheongbuk-do, Korea; wlghks8453@naver.com \\ 4 Department of Advanced Energy Engineering, Chosun University, 309 Pilmun-daero, Dong-gu, \\ Gwangju 61452, Korea \\ * Correspondence: jp@chosun.ac.kr
}

check for updates

Citation: Song, Y.-J.; Oh, K.-S.; Lee, B.; Pak, D.-W.; Cha, J.-H.; Park, J.-G. Characteristics of Biogas Production from Organic Wastes Mixed at Optimal Ratios in an Anaerobic Co-Digestion Reactor. Energies 2021, 14, 6812. https://doi.org/10.3390/ en14206812

Academic Editor: Gabriele Di Giacomo

Received: 30 August 2021

Accepted: 11 October 2021

Published: 18 October 2021

Publisher's Note: MDPI stays neutral with regard to jurisdictional claims in published maps and institutional affiliations.

Copyright: (c) 2021 by the authors. Licensee MDPI, Basel, Switzerland. This article is an open access article distributed under the terms and conditions of the Creative Commons Attribution (CC BY) license (https:/ / creativecommons.org/licenses/by/ $4.0 /)$.

\begin{abstract}
This study determined the optimal mixing ratio of food waste and livestock manure for efficient co-digestion of sewage sludge by applying the biochemical methane potential (BMP) test, Design Expert software, and continuous reactor operation. The BMP test of sewage sludge revealed a maximum methane yield of $334 \mathrm{~mL} \mathrm{CH}_{4} / \mathrm{g}$ volatile solids (VS) at an organic loading rate (OLR) of $4 \mathrm{~kg} \mathrm{VS} /\left(\mathrm{m}^{3} \cdot \mathrm{d}\right)$. For food waste, the maximum methane yield was $573 \mathrm{~mL} \mathrm{CH}_{4} / \mathrm{g} \mathrm{VS}$ at an OLR of $6 \mathrm{~kg} \mathrm{VS} /\left(\mathrm{m}^{3} \cdot \mathrm{d}\right)$. Livestock manure showed the lowest methane yield. The BMP tests with various mixing ratios confirmed that a higher mixing ratio of food waste resulted in a higher methane yield, which showed improved biodegradability and an improved VS removal rate. The optimal mixing ratio of 2:1:1 for sewage sludge, food waste, and livestock manure was determined using Design Expert 10. Using continuous co-digestion reactor operation under an optimal mixing ratio, greater organic matter removal and methane yield was possible. The process stability of co-digestion of optimally mixed substrate was improved compared with that of operations with each substrate alone. Therefore, co-digestion could properly maintain the balance of each stage of anaerobic digestion reactions by complementing the characteristics of each substrate under a higher OLR.
\end{abstract}

Keywords: sewage sludge; food waste; livestock manure; anaerobic co-digestion; mixing ratio

\section{Introduction}

Although the amount of sewage sludge is increasing owing to economic and population growth, sewage sludge treatment, and disposal are limited by existing methods because of the prohibition of sea dumping by the 1972 London Convention and 1996 London Protocol [1,2]. Landfilling, incineration, and recycling are alternative methods to marine dumping. However, these methods are difficult to develop and secure owing to limitations such as landfill capacity and air pollution [3]. Anaerobic digestion (AD) can eliminate harmful bacteria, reduce organic waste, and produce biogas while consuming less energy than aerobic digestion and, thus, is a promising technique for waste sludge management [4]. Despite its various advantages, most AD reactors cannot meet the design standard of $1.6-4.8 \mathrm{~kg}$ volatile solids $(\mathrm{VS}) /\left(\mathrm{m}^{3} \cdot \mathrm{d}\right)$ owing to the low biodegradable organic fraction. therefore, most engineered AD reactors are operated at a lower efficiency (20-40\%) than the actual designed efficiency [5]. In addition to these problems, AD is sensitively affected by operational factors such as $\mathrm{pH}$, temperature, nutrients, and toxic substances. Obtaining a high process stability is not easy because of problems such as a long hydraulic residence time and a low growth rate of methanogenic bacteria [6]. 
The aim of recent studies on the use of AD to treat sewage sludge was to improve digestion efficiency by modifying existing AD reactors. Representative techniques for increasing the digestion efficiency in the AD of sewage sludge can be divided into two types, namely, pretreatment of sewage sludge [7] and co-digestion with organic wastes such as food waste and livestock manure [8]. Pretreatment technology can increase the biodegradability of waste sludge by destroying the cell walls of microorganisms in the excess sludge generated by the sewage treatment process [7]. This process includes mechanical, chemical, and thermal treatment methods. Ultrasonication is a representative mechanical pretreatment method that destroys the cell walls of microorganisms by applying tension, pressure, and rotational force. The ultrasonic treatment utilizes the cavitation phenomenon caused by high-temperature and high-pressure gases generated during repeated adiabatic expansion [9]. Thermal pretreatment increases the digestion efficiency by converting particulate organics into soluble organics under high-temperature conditions, thereby resulting in improved hydrolysis efficiency [10]. Chemical pretreatment promotes sludge hydrolysis by injecting caustic soda and lime to create alkaline conditions [10]. Various physicochemical pretreatment technologies are being studied, but they require additional space for installing facilities and advanced operational skills and have high operating costs [8].

Co-digestion is a promising concept for improving AD efficiency by mixing and processing sewage sludge with other organic wastes, such as food waste and livestock manure. These substrates are used as representative organic wastes for the production of biogas and digestate worldwide. Therefore, the influence of the production and accumulation of other unexpected substances via co-digestion may not be considerable, and co-digestion would be effective in balancing each AD reaction step. Co-digestion can improve biodegradability, dilute toxic substances, and balance each reaction rate. It can also provide an optimum $\mathrm{C} / \mathrm{N}$ ratio of 6-16 or 25-30 for efficient AD process operation. It has been reported that co-digestion can improve the overall energy efficiency by covering the input electricity used in sewage treatment facilities because the biogas production of co-digestion is higher than that of conventional AD of sewage sludge [8]. However, in the case of co-digestion, it is difficult to calculate an appropriate mixing ratio because the properties of each organic waste are different in mixed organic wastes.

Therefore, in this study, the optimum mixing ratio of sewage sludge, food waste, and livestock manure was determined, and the methane production performance and process stability of the optimally mixed substrate in a co-digestion reactor were evaluated.

\section{Materials and Methods}

\subsection{Biochemical Methane Potential Test}

\subsubsection{Substrates and Inoculum Characterization}

The biodegradability of each sample can be predicted by conducting an elemental analysis of organic waste, which is important for designing treatment facilities. Sewage sludge was collected from a sewage treatment facility in city $\mathrm{C}$ in South Korea before the sewage sludge inflowed to the dewatering process. Food waste was also collected from a food waste collection vehicle in the same area, and livestock manure was collected from L farmhouses in city C. The collected samples were dried at $110^{\circ} \mathrm{C}$, and the dry samples were analyzed to determine the chemical compositions of carbon, hydrogen, nitrogen, oxygen, and sulfur using an elemental analyzer (TruSpec CHN Elemental Analyzer, LECO Co., St. Joseph, MI, USA) and a sulfur analyzer (SC-432DR Sulfur Analyzer, LECO Co.). A nutrient medium was prepared according to the method of a previous study [11] and was supplied to biochemical methane potential (BMP) test reactors. The prepared nutrient medium was sterilized for 30 min using a high-pressure sterilizer, and the oxygen in the microbial medium was discharged by purging with nitrogen. 


\subsubsection{BMP Test}

In this study, the BMP test was performed according to Owen's method [11] at a constant temperature $\left(35^{\circ} \mathrm{C}\right)$ to maintain mesophilic AD conditions. Nitrogen gas was injected into a serum bottle with an actual volume of $635 \mathrm{~mL}$, and $300 \mathrm{~mL}$ of microbial medium and $30 \mathrm{~mL}$ of seeding sludge were then injected. In the BMP test, each organic waste was injected based on $1 \mathrm{~g} \mathrm{VS} / \mathrm{L}$, and $1 \mathrm{~N} \mathrm{NaOH}$ and $1 \mathrm{~N} \mathrm{HCl}$ were added to adjust the $\mathrm{pH}$ of the reaction tank to neutral ( $\mathrm{pH}$ of 7.0$)$. Bicarbonate $(1.2 \mathrm{~g} / \mathrm{L}$ ) was injected to prevent the decrease in $\mathrm{pH}$ caused by the acid formation in reactors [11]. After purging with nitrogen gas, $\mathrm{AD}$ was induced for the sewage sludge pretreated in the heating mantle at $35^{\circ} \mathrm{C}$. The time when the temperature inside the serum bottle reached $35^{\circ} \mathrm{C}$ was used as the BMP test start time. The theoretical maximum methane production was calculated using the molecular formula obtained from the chemical composition data of the organic waste and Buswell's equation [12]. The stoichiometric amounts of methane, carbon dioxide, and ammonia were calculated by substituting the elemental analysis results into the formula established by Owen et al. [11].

\subsubsection{Analysis of Biogas Production and Methane Content}

The amount of methane generated $(V)$ during the measurement period was corrected for the amount of methane that existed in the headspace of the reaction tank before the collection time of the corresponding gas sample using the mass balance formula, as shown in Equation (1) [11].

$$
V_{\mathrm{CH}_{4}}=C_{1}\left(V_{1}+V_{0}\right)-C_{0} V_{0}
$$

where $V_{\mathrm{CH} 4}$ is the produced methane volume (mL), $C_{1}$ is the methane content (\%) at the sampling time, $C_{0}$ is the methane content (\%) at the previous sampling time, $V_{1}$ is the biogas volume measured using a syringe $(\mathrm{mL})$, and $V_{0}$ is the gas phase volume of the reactor $(\mathrm{mL})$.

The amount of methane calculated in the above equation can be converted to the normal state at $0{ }^{\circ} \mathrm{C}$ and $1 \mathrm{~atm}$ using Equation (2), and then the accumulated amount of methane can be calculated [11]. This subtracted $42.2 \mathrm{~mm} \mathrm{Hg}$ of saturated water vapor pressure at $35^{\circ} \mathrm{C}$ to obtain the generated dry gas yield. The cumulative amount of methane generated was subsequently corrected.

$$
\mathrm{V}_{\mathrm{CH}_{4}, \mathrm{~N}}=V_{\mathrm{CH}_{4}, d i g} \times \frac{T_{N}}{T_{\mathrm{dig}}} \times \frac{P_{\text {dig }}}{P_{N}}
$$

where, $V_{\mathrm{CH} 4, N}$ is the methane volume under normal conditions $(\mathrm{mL}), V_{\mathrm{CH} 4, \text { dig }}$ is the methane volume under digester conditions $(\mathrm{mL}), T_{N}$ is the temperature under normal conditions $(273 \mathrm{~K}), T_{\text {dig }}$ is the temperature under digester conditions $(308 \mathrm{~K}), P_{N}$ is the atmospheric pressure under normal conditions $(760.0 \mathrm{~mm} \mathrm{Hg})$, and $P_{\text {dig }}$ is the atmospheric pressure under digester conditions $(717.8 \mathrm{~mm} \mathrm{Hg})$.

\subsubsection{Final Methane Yield and Methane Production Rate Constant}

According to Owen et al. (1979), when it was assumed that the substrate was a limiting factor and that there was no effect of the concentration of microorganisms on the degradation of organic matter, it could be considered that the consumed substrate was converted to methane. If the relational formula with the amount generated was expressed as follows, the amount of methane generated $\left(B ; \mathrm{mL} \mathrm{CH}_{4} / \mathrm{g}\right.$ VS) can be derived from Equation (3) [11].

$$
B=B_{u}\left(1-e^{-k t}\right)
$$

where $B_{u}$ is the ultimate methane yield $\left(\mathrm{mL} \mathrm{CH}_{4} / \mathrm{g} \mathrm{VS}\right)$ and $B$ is the accumulated methane yield ( $\left.\mathrm{mL} \mathrm{CH}_{4} / \mathrm{g} \mathrm{VS}\right)$. 
The reaction rate constant $k$ can be obtained from the relationship $\ln \left(B_{u}-B\right) / B$ with respect to time $(t)$. The first $k$ value obtained here is reported as a factor that can be used to evaluate the biodegradation and decomposition rates for various target substrates.

\subsubsection{Biodegradability Assessment}

The biodegradability of each organic waste was evaluated using the experimental results for the investigation of potential biogas yield. Because the term "biodegradability" was used interchangeably in various studies, in this study, it was defined as the ratio of the final methane yield to the theoretical methane yield. It was evaluated using the theoretical methane yield calculated using Buswell's equation, as shown in Equation (4), and the cumulative methane yield in this study [12].

$$
\text { Biodegradability }(\%)=\frac{C M Y}{T M Y} \times 100
$$

where, CMY is the cumulative methane yield, and TMY is the theoretical methane yield.

\subsection{Evaluation of Biogas Production According to the Mixing Ratio}

The mixing ratio of pretreated sewage sludge, food waste, and livestock manure that can satisfy the target VS removal rate, biodegradability, and methane yield was evaluated using tree-based classification and regression methods [13]. These methods were used in decision analysis to illustrate the decisions made in a visual, explicit way. Independent variables can be applied to both categorical and continuous types, and after repeating this process, the final predictive model is selected via pruning to determine an appropriate tree model. Tree models were divided into classification and regression trees according to the data input and output types. In a classification tree, the prediction results were classified by class, whereas in a regression tree, the prediction results were output as real values with specific meanings. The CART package in $\mathrm{R}$ studio was used, and the desired output results (the VS removal rate, biodegradation rate, and methane production rate) were determined. When data (the substrate mixing ratio) were input according to different scenarios, tree-classifying data were produced according to the mixing ratios. Based on the derived results, multiple linearity and variance analyses were performed, and the status of organic waste degradation and an appropriate mixing ratio for the stable operation was derived using Design Expert 10 [14].

\subsection{Analysis Method}

Water quality analyses were conducted to determine factors such as $\mathrm{pH}$, total solids (TS), VS, total chemical oxygen demand (COD), soluble COD, and volatile fatty acids (VFAs) for each organic waste. Quantitative and qualitative analyses of biogas were performed using chromatography; the analysis items and experimental methods are presented in Table 1. Spearman's correlation analysis was performed to confirm the correlations among the theoretical methane yield, actual methane yield, and biodegradability of each substrate (R 4.1.1 program).

Table 1. Detailed measurement methods.

\begin{tabular}{cr}
\hline Items & Analysis Methods \\
\hline $\mathrm{pH}$ & $\mathrm{pH}$ meter (Thermo Orion model 420A ${ }^{+}, \mathrm{USA}^{\text {(T) }}$ \\
\hline TS and VS & Standard method [15] \\
\hline TCOD $_{\mathrm{Cr}}$ and SCOD $\mathrm{Cr}$ & Closed reflux and colorimetric chrome method [15] \\
\hline VFAs & $\begin{array}{c}\text { Liquid chromatograph (SDV50A, Younglin, Korea) equipped } \\
\text { with a UV725S absorbance detector }\end{array}$ \\
\hline Alkalinity & Standard method [15] \\
\hline Biogas composition & $\begin{array}{c}\text { Gas chromatograph (580 series, Gow-Mac, Bethlehem, PA, } \\
\text { USA) coupled with a thermal conductivity detector }\end{array}$
\end{tabular}




\section{Results}

\subsection{Evaluation of Biodegradability According to the Input Substrate}

The biodegradability of organic waste refers to the degree of biodegradable organic components in the substrates, which show significant differences according to physicochemical properties [16]. The degree of biodegradation is an essential factor for the design and operation of $\mathrm{AD}$ reactors; therefore, a clear understanding of the biodegradation characteristics of the substrates is required [17]. The biodegradability of particulate organic matter can be determined by measuring the ratio of biodegradable volatile solids (BVS) to total volatile solids (TVS) in the substrates [18]. Only the BVS portion of the TVS of the target substrate was decomposed into biogas; thus, the degree of BVS can be predicted by measuring the methane yield. In this section, the biodegradability of each substrate was evaluated by analyzing the theoretical and actual methane yield of sewage sludge, food waste, and livestock manure, which were the substrates studied to determine the appropriate mixing ratios.

\subsubsection{Analysis of Organic Waste Properties}

Among the organic wastes studied, livestock manure showed the highest $\mathrm{pH}$, followed by sewage sludge and food waste. Food waste exhibited the highest TS, followed by livestock manure and sewage sludge. Food waste showed the highest total nitrogen (TN) value among all the organic wastes, followed by livestock manure and sewage sludge. TN includes organic nitrogen (such as proteins) and inorganic nitrogen (ammonium nitrogen, nitrite nitrogen, and nitrate nitrogen), and a portion of the organic nitrogen is converted to ammonia by proteolysis during $\mathrm{AD}[18,19]$. The ammonia concentration was the highest in livestock manure, followed by food waste and sewage sludge. In livestock manure, ammonia nitrogen accounted for $70 \%$ of $\mathrm{TN}$; therefore, the proportion of inorganic nitrogen was the highest in livestock manure among the substrates. The main properties of the substrates used in this study are summarized in Table 2.

Table 2. Main properties of the substrates used in this study.

\begin{tabular}{cccc}
\hline \multicolumn{2}{c}{ Classification (Unit) } & Range & $\begin{array}{c}\text { Average and } \\
\text { Standard Deviation }\end{array}$ \\
\hline & $\mathrm{pH}$ & $7.27 \sim 7.56$ & $7.47 \pm 0.14$ \\
Sewage & $\mathrm{TS}(\mathrm{mg} / \mathrm{L})$ & $24,479.12 \sim 27,499.72$ & $25,892.72 \pm 1241.83$ \\
sludge & $\mathrm{VS}(\mathrm{mg} / \mathrm{L})$ & $15,402.74 \sim 17,113.43$ & $16,280.81 \pm 699.43$ \\
& $\mathrm{TCOD}_{\mathrm{Cr}}(\mathrm{mg} / \mathrm{L})$ & $28,017.78 \sim 30,259.81$ & $29,256.67 \pm 930.82$ \\
& $\mathrm{SCOD}_{\mathrm{Cr}}(\mathrm{mg} / \mathrm{L})$ & $936.26 \sim 1072.33$ & $1012.83 \pm 57.09$ \\
$\mathrm{VS} / \mathrm{TS}$ & $0.56 \sim 0.62$ & $0.59 \pm 0.02$ \\
\hline \multirow{5}{*}{ Food } & $\mathrm{pH}$ & $3.74 \sim 3.94$ & $3.87 \pm 0.09$ \\
waste & $\mathrm{TS}(\mathrm{mg} / \mathrm{L})$ & $194,120.72 \sim 213,530.85$ & $207,060.89 \pm 9150.04$ \\
& $\mathrm{VS}(\mathrm{mg} / \mathrm{L})$ & $113,400.57 \sim 126,000.11$ & $117,600.46 \pm 5940.52$ \\
& $\mathrm{TCOD}(\mathrm{mg} / \mathrm{L})$ & $171,500.24 \sim 186,950.46$ & $178,937.65 \pm 6321.38$ \\
& $\mathrm{SCOD}(\mathrm{mg} / \mathrm{L})$ & $75,679.68 \sim 81,730.51$ & $78,777.62 \pm 2472.78$ \\
& $\mathrm{VS} / \mathrm{TS}$ & $0.56 \sim 0.65$ & $0.62 \pm 0.04$ \\
\hline & $\mathrm{pH}$ & $7.14 \sim 7.48$ & $7.26 \pm 0.17$ \\
Livestock & $\mathrm{TS}(\mathrm{mg} / \mathrm{L})$ & $51,280 \sim 54,360$ & $53,153 \pm 1343$ \\
manure & $\mathrm{VS}(\mathrm{mg} / \mathrm{L})$ & $25,490 \sim 27,790$ & $26,997 \pm 1066$ \\
& $\mathrm{TCOD}(\mathrm{mg} / \mathrm{L})$ & $51,250 \sim 55,710$ & $53,170 \pm 1873$ \\
& $\mathrm{SCD}_{\mathrm{Cr}}(\mathrm{mg} / \mathrm{L})$ & $42,130 \sim 50,100$ & $45,910 \pm 3267$ \\
& $\mathrm{VS} / \mathrm{TS}$ & $0.47 \sim 0.54$ & $0.51 \pm 0.03$ \\
\hline
\end{tabular}

\subsubsection{Chemical Composition}

To evaluate the chemical composition of sewage sludge, food waste, and livestock manure, the carbon, hydrogen, oxygen, nitrogen, and sulfur contents were analyzed according to the organic loading rate (OLR) (Table 3). The chemical composition can allow the estimation of the theoretical biogas yield for the organic wastes and was used as basic 
data for evaluating biodegradability. In particular, the carbon content in organic waste is directly related to the amount of biogas yield because it is converted into methane and carbon dioxide during anaerobic decomposition. The elemental composition analysis of sewage sludge, food waste, and livestock manure indicated that the carbon content increased as the OLR increased, whereas the hydrogen and oxygen contents decreased as the OLR increased.

Table 3. Chemical composition of organic waste.

\begin{tabular}{|c|c|c|c|c|c|c|c|}
\hline \multirow[b]{2}{*}{ Parameter } & \multicolumn{7}{|c|}{ Chemical Composition (\%, Dry) } \\
\hline & $\begin{array}{c}\text { OLR (kg } \\
\text { VS/(m } / \mathrm{d}))\end{array}$ & $\mathrm{C}$ & $\mathbf{H}$ & $\mathbf{O}$ & $\mathbf{N}$ & $\mathrm{S}$ & $\mathrm{C} / \mathrm{N}$ \\
\hline \multirow{4}{*}{$\begin{array}{l}\text { Sewage } \\
\text { sludge }\end{array}$} & 2 & $35.2 \pm 2.4$ & $5.5 \pm 0.3$ & $23.8 \pm 0.9$ & $6.3 \pm 0.5$ & $1.2 \pm 0.1$ & $5.6 \pm 0.3$ \\
\hline & 4 & $35.5 \pm 2.9$ & $5.5 \pm 0.4$ & $23.6 \pm 2.0$ & $6.3 \pm 0.4$ & $1.7 \pm 0.1$ & $5.6 \pm 0.5$ \\
\hline & 6 & $36.1 \pm 2.2$ & $5.4 \pm 0.5$ & $23.1 \pm 2.2$ & $6.1 \pm 0.4$ & $1.6 \pm 0.1$ & $5.9 \pm 0.4$ \\
\hline & 8 & $36.5 \pm 3.7$ & $5.2 \pm 0.1$ & $22.3 \pm 1.1$ & $6.0 \pm 0.1$ & $1.6 \pm 0.1$ & $6.1 \pm 0.4$ \\
\hline \multirow{4}{*}{$\begin{array}{l}\text { Food } \\
\text { waste }\end{array}$} & 2 & $46.9 \pm 2.4$ & $6.9 \pm 0.5$ & $26.0 \pm 2.5$ & $4.2 \pm 0.3$ & $0.8 \pm 0.1$ & $11.1 \pm 0.6$ \\
\hline & 4 & $47.4 \pm 2.5$ & $6.8 \pm 0.4$ & $25.5 \pm 2.1$ & $4.3 \pm 0.2$ & $0.8 \pm 0.1$ & $11.0 \pm 0.6$ \\
\hline & 6 & $48.3 \pm 1.4$ & $6.7 \pm 0.5$ & $25.0 \pm 0.3$ & $4.3 \pm 0.3$ & $0.8 \pm 0.1$ & $11.2 \pm 0.5$ \\
\hline & 8 & $48.3 \pm 3.0$ & $6.7 \pm 0.5$ & $24.8 \pm 1.6$ & $4.3 \pm 0.4$ & $0.7 \pm 0.1$ & $11.2 \pm 1.0$ \\
\hline \multirow{4}{*}{$\begin{array}{l}\text { Livestock } \\
\text { manure }\end{array}$} & 2 & $42.6 \pm 1.2$ & $5.8 \pm 0.5$ & $34.1 \pm 2.4$ & $4.1 \pm 0.3$ & $2.3 \pm 0.2$ & $10.1 \pm 1.0$ \\
\hline & 4 & $43.0 \pm 2.6$ & $5.7 \pm 0.6$ & $34.1 \pm 2.1$ & $4.0 \pm 0.2$ & $2.4 \pm 0.1$ & $10.8 \pm 0.1$ \\
\hline & 6 & $43.8 \pm 3.1$ & $5.6 \pm 0.2$ & $33.4 \pm 2.4$ & $3.9 \pm 0.3$ & $2.4 \pm 0.1$ & $11.2 \pm 0.7$ \\
\hline & 8 & $44.7 \pm 1.4$ & $5.6 \pm 0.4$ & $32.7 \pm 2.1$ & $3.9 \pm 0.2$ & $2.6 \pm 0.1$ & $11.5 \pm 0.8$ \\
\hline
\end{tabular}

\subsubsection{Cumulative Methane Yield Assessment}

The results of the VS-based cumulative methane yields are shown in Figure 1. Methane production from food waste was shown after day 2 of operation, followed by that from sewage sludge (after day 5) and livestock manure (after day 7). The cumulative methane yield of food waste increased up to an OLR of $6 \mathrm{~kg}$ VS but showed a significant decrease at an OLR of $8 \mathrm{~kg}$ VS. The $\mathrm{pH}$ at $8 \mathrm{~kg}$ VS was approximately 1.2 units lower than that at $6 \mathrm{~kg} \mathrm{VS}$, which might have been due to the accumulation of VFAs [20]. For sewage sludge, the cumulative methane yield increased up to $4 \mathrm{~kg}$ VS but showed a tendency to decrease at $6 \mathrm{~kg}$ VS. The pH was 6.3 under $6 \mathrm{~kg}$ VS and 6.0 under $8 \mathrm{~kg}$ VS at the end of each OLR. Similar to the food waste results, the higher OLR accelerated the acidogenesis reaction, thereby resulting in a decrease in $\mathrm{pH}$ due to the accumulation of VFAs. The results of the BMP tests revealed that the methane yield and production rate decreased as the OLR increased. The methane production rates of each substrate were significantly different according to the OLR, which indicated that co-digestion could balance the reaction during AD by supporting more biodegradation and possibly improve the performance of AD of sewage sludge and livestock manure under a higher OLR [21].

\subsubsection{Biodegradability Assessment}

As shown in Table 4, increasing carbon content in the substrate according to the OLR affected the theoretical methane yield. The biodegradability of the sewage sludge-based on cumulative methane yields at 2, 4, 6, and $8 \mathrm{~kg}$ VS was 51.8\%, 54.3\%, 52.2\%, and 36.8\%, respectively. The biodegradability of food waste at 2, 4,6, and $8 \mathrm{~kg}$ VS was $73.6 \%, 76.5 \%$, $77.0 \%$, and $57.0 \%$, respectively. The biodegradability of livestock manure at $2,4,6$, and $8 \mathrm{~kg}$ VS was $49.5 \%, 43.3 \%, 25.6 \%$, and $17.8 \%$, respectively. The process stability of AD of livestock manure was the lowest among that of all the substrates. As shown in Figure 2, each substrate showed a strong negative correlation $(r=-0.52-0.85)$ between the theoretical methane yield and methane yield, but there was a positive correlation between the actual methane yield and methane yield ( $r=0.43-0.79)$. This result was interpreted as the reason for the lower methane yield than the theoretical methane yield [22]. There was also a positive correlation $(r=0.47-0.79)$ between biodegradability and the actual methane yield, and all the $p$-values $(<0.05)$ indicated a significant correlation. These results indicate that biodegradability has a significant effect on methane yield [17]. In addition, there was a very 
strong correlation between biodegradability and the actual methane yield, which showed an $r$ value of $0.88-1.00$, which indicates that biodegradability has a substantial effect on the actual methane yield.

a

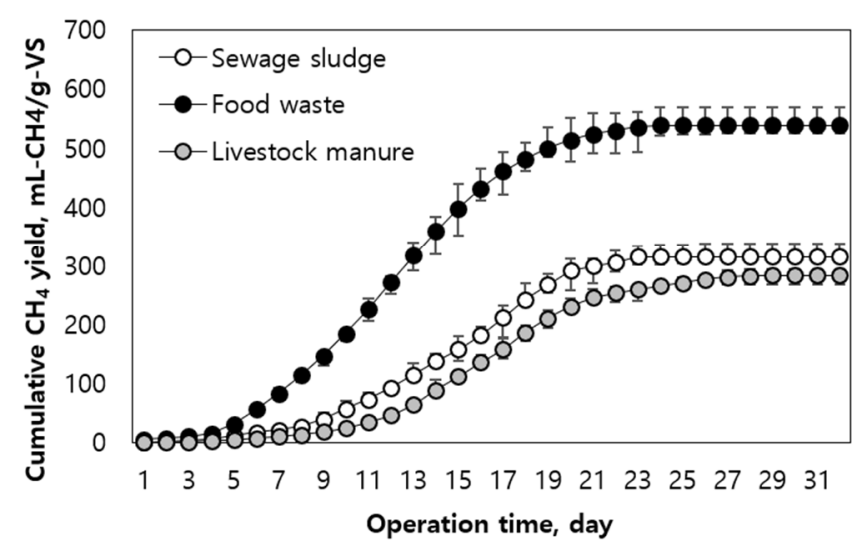

c

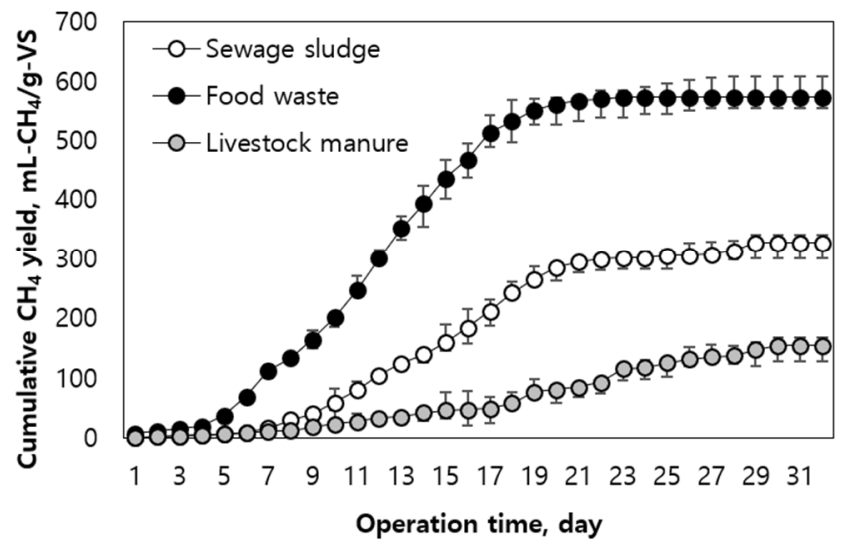

b

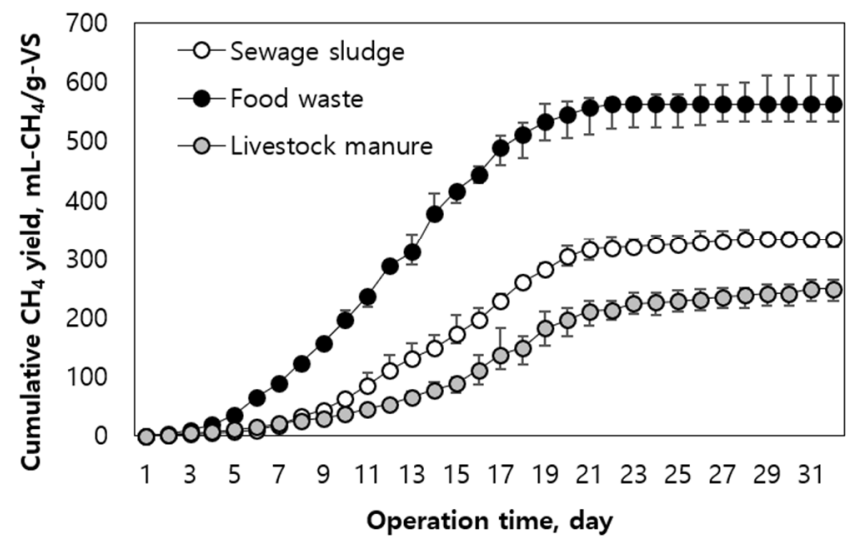

d

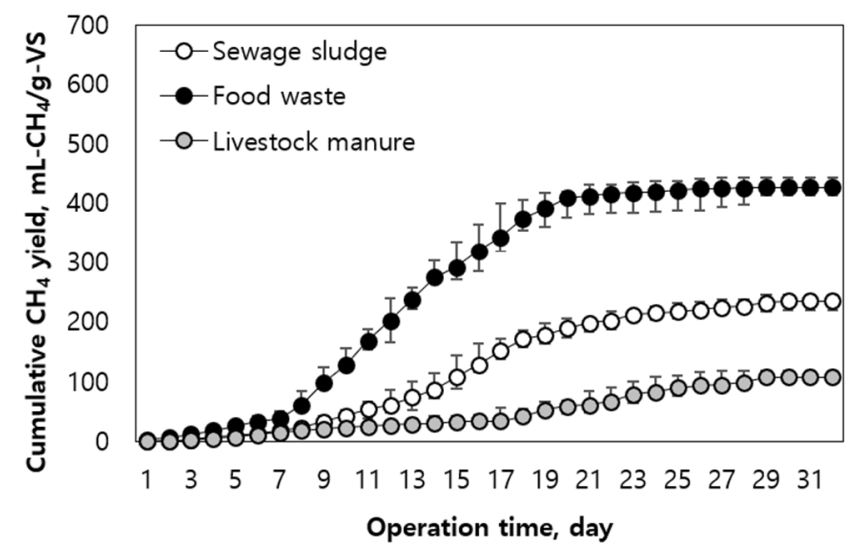

Figure 1. Cumulative methane yields of each organic waste under various organic loading rates of (a) $2 \mathrm{~kg}$ VS, (b) $4 \mathrm{~kg}$ VS, (c) $6 \mathrm{~kg} \mathrm{VS}$, and (d) $8 \mathrm{~kg}$ VS.

Table 4. Biodegradability and volatile solids (VS)-based methane yield.

\begin{tabular}{|c|c|c|c|c|}
\hline Parameter & $\begin{array}{c}\text { OLR (kg } \\
\text { VS/(m².d)) }\end{array}$ & $\begin{array}{c}\text { Theoretical } \\
\text { Methane Yield } \\
\text { (mL CH } / \text { g VS) }\end{array}$ & $\begin{array}{c}\text { Actual } \\
\text { Methane Yield } \\
\left(\mathrm{mL} \mathrm{CH}_{4} / \mathrm{g} \text { VS) }\right.\end{array}$ & $\begin{array}{c}\text { Biodegradability } \\
(\%)\end{array}$ \\
\hline \multirow{4}{*}{$\begin{array}{l}\text { Sewage } \\
\text { sludge }\end{array}$} & 2 & $0.62 \pm 0.05$ & $0.32 \pm 0.07$ & $51.8 \pm 1.1$ \\
\hline & 4 & $0.31 \pm 0.03$ & $0.17 \pm 0.02$ & $54.3 \pm 1.0$ \\
\hline & 6 & $0.21 \pm 0.04$ & $0.11 \pm 0.01$ & $52.2 \pm 1.3$ \\
\hline & 8 & $0.16 \pm 0.05$ & $0.06 \pm 0.01$ & $36.8 \pm 0.5$ \\
\hline \multirow{4}{*}{$\begin{array}{l}\text { Food } \\
\text { waste }\end{array}$} & 2 & $0.73 \pm 0.03$ & $0.54 \pm 0.03$ & $73.6 \pm 1.2$ \\
\hline & 4 & $0.37 \pm 0.05$ & $0.28 \pm 0.02$ & $76.5 \pm 1.3$ \\
\hline & 6 & $0.25 \pm 0.04$ & $0.19 \pm 0.02$ & $77.0 \pm 1.6$ \\
\hline & 8 & $0.19 \pm 0.03$ & $0.11 \pm 0.01$ & $57.0 \pm 1.0$ \\
\hline \multirow{4}{*}{$\begin{array}{l}\text { Livestock } \\
\text { manure }\end{array}$} & 2 & $0.57 \pm 0.03$ & $0.28 \pm 0.02$ & $49.5 \pm 2.7$ \\
\hline & 4 & $0.18 \pm 0.02$ & $0.08 \pm 0.01$ & $43.3 \pm 1.6$ \\
\hline & 6 & $0.31 \pm 0.02$ & $0.08 \pm 0.01$ & $25.6 \pm 2.1$ \\
\hline & 8 & $0.17 \pm 0.04$ & $0.03 \pm 0.00$ & $17.8 \pm 2.2$ \\
\hline
\end{tabular}


a

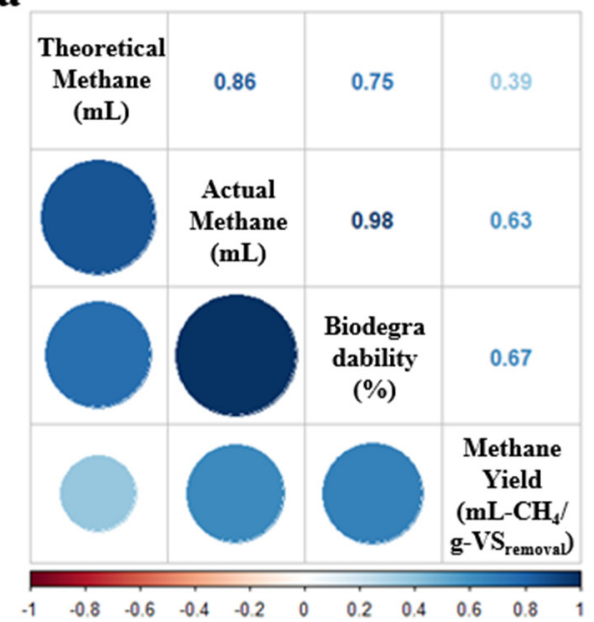

c

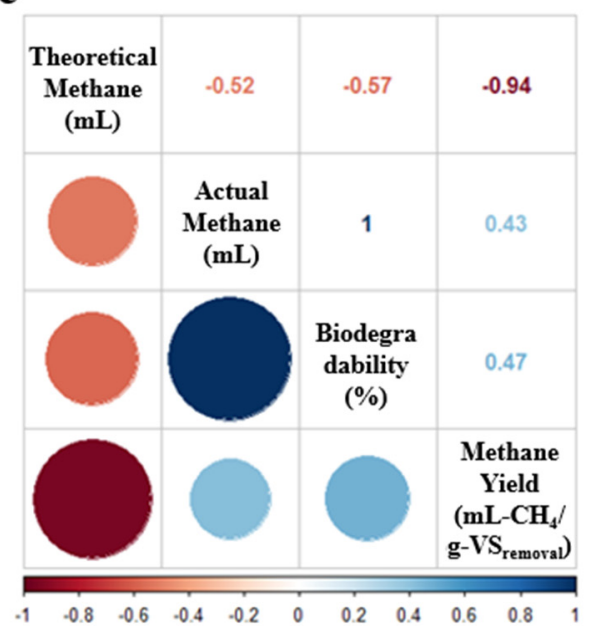

b

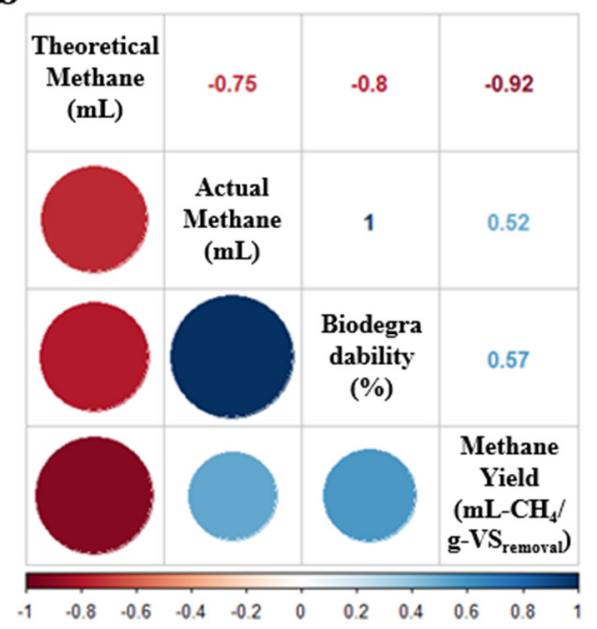

d

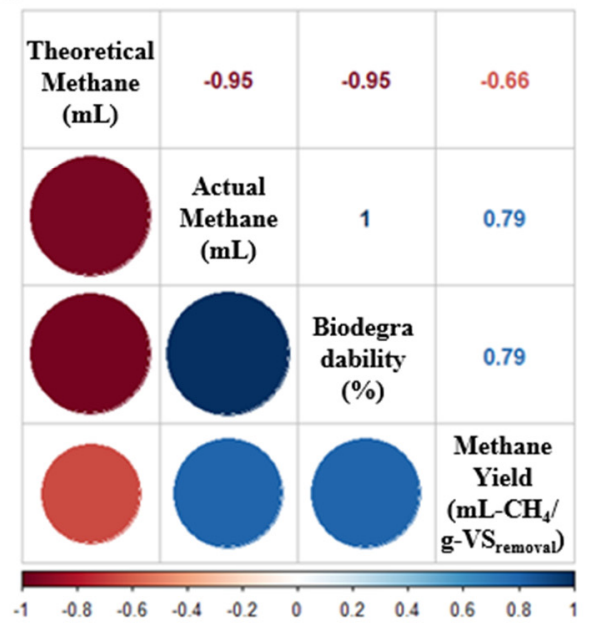

Figure 2. Correlation between environmental variables (Spearman's correlation coefficient): (a) total; (b) sewage sludge; (c) food waste; (d) livestock manure.

\subsection{Evaluation of Biogas Production by the Mixing Ratio}

\subsubsection{BMP Test Result According to the Mixing Ratio}

The mixing ratios were derived using the tree-based classification and regression to evaluate the methane yield in accordance with the mixing ratio. The BMP tests were performed for each mixing ratio to determine the VS removal rate according to the mixing ratio, biodegradability, and optimum conditions for methane production. Based on the derived results, multiple linearity and variance analyses were performed [23]. The status of organic waste degradation and an appropriate mixing ratio for the stable operation was determined using Design Expert 10, as summarized in Table 5 [24].

The BMP test results according to the mixing ratio are shown in Figure 3 and Table 6. The cumulative methane production during Run 7 was the highest with a methane yield of $482 \mathrm{~mL} \mathrm{CH}_{4} / \mathrm{g} \mathrm{VS}$, whereas the cumulative methane production during Run 9 was the lowest with a methane yield of $306 \mathrm{~mL} \mathrm{CH}_{4} / \mathrm{g}$ VS. The cumulative methane production was affected by the mixing ratio, and it was found that a higher mixing ratio of food waste showed a higher cumulative methane production [25]. As the biodegradability was calculated via the actual methane production, Runs 7 and 8 , which had high mixing ratios of food waste, revealed improved biodegradability values of $68.3 \%$ and $67.2 \%$, respectively. However, Runs 5 and 9, which had low mixing ratios of food waste, had low biodegradability of $51.0 \%$ and $50.0 \%$, respectively. The VS removal rate was also similar 
to the biodegradability results, which showed that Run 9 had the lowest removal rate of $50.8 \%$ and Run 8 had the highest removal rate of $70.9 \%$.

Table 5. Classification and regression mixing ratios according to trees.

\begin{tabular}{|c|c|c|c|c|c|}
\hline \multicolumn{4}{|c|}{ Plan } & \multicolumn{2}{|c|}{ Experiment } \\
\hline \multirow{2}{*}{ Run } & \multicolumn{3}{|c|}{ Mixing Ratio (\% of Substrate Volume) } & \multirow{2}{*}{ Run } & \multirow{2}{*}{ Application } \\
\hline & Sewage Sludge & Food Waste & Livestock Manure & & \\
\hline 1 & 50 & 50 & - & 1 & O \\
\hline 2 & - & 50 & 50 & 2 & O \\
\hline 3 & 50 & - & 50 & & \\
\hline 4 & 50 & 25 & 25 & 3 & $\bigcirc$ \\
\hline 5 & 25 & 50 & 25 & 4 & O \\
\hline 6 & 25 & 25 & 50 & 5 & O \\
\hline 7 & 75 & 25 & - & 6 & O \\
\hline 8 & 75 & - & 25 & & \\
\hline 9 & 25 & 75 & - & 7 & 0 \\
\hline 10 & - & 75 & 25 & 8 & 0 \\
\hline 11 & 25 & - & 75 & & \\
\hline 12 & - & 25 & 75 & 9 & 0 \\
\hline 13 & 100 & - & - & & \\
\hline 14 & - & 100 & - & & \\
\hline 15 & - & - & 100 & & \\
\hline
\end{tabular}

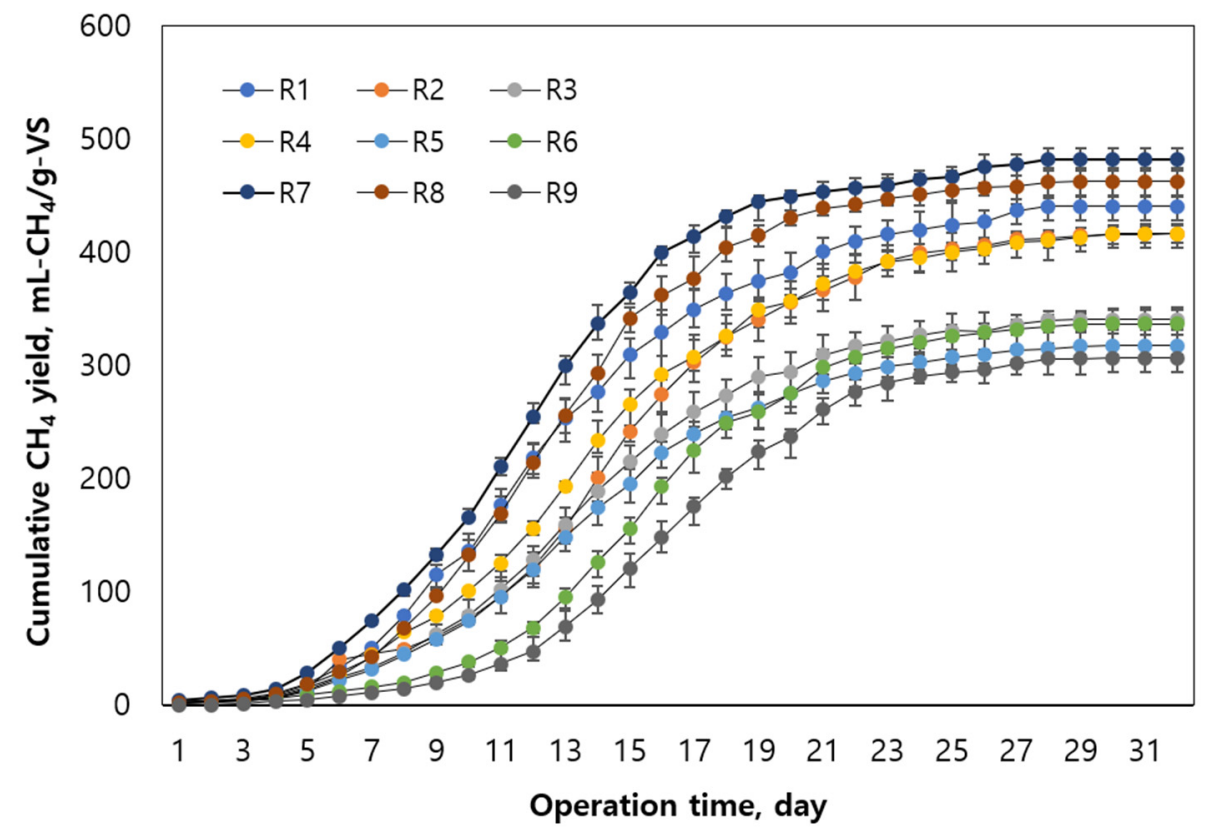

Figure 3. Cumulative methane yield in accordance with various mixing ratios. 
Table 6. Volatile solids (VS) removal rate and biodegradability according to the mixing ratio.

\begin{tabular}{ccccc}
\hline Run & $\begin{array}{c}\text { Theoretical } \\
\text { Methane Yield } \\
\left(\mathbf{m L} \mathbf{C H}_{\mathbf{4}} / \mathbf{g} \text { VS) }\right.\end{array}$ & $\begin{array}{c}\text { Actual } \\
\text { Methane Yield } \\
\left(\mathbf{m L} \mathbf{C H}_{\mathbf{4}} / \mathbf{g} \text { VS) }\right.\end{array}$ & $\begin{array}{c}\text { VS Removal } \\
\text { Efficiency (\%) }\end{array}$ & $\begin{array}{c}\text { Biodegradability } \\
\mathbf{( \% )}\end{array}$ \\
\hline 1 & $0.69 \pm 0.05$ & $0.45 \pm 0.03$ & $61.8 \pm 3.1$ & $65.1 \pm 3.4$ \\
\hline 2 & $0.61 \pm 0.03$ & $0.39 \pm 0.05$ & $66.4 \pm 2.4$ & $64.1 \pm 3.1$ \\
\hline 3 & $0.65 \pm 0.04$ & $0.35 \pm 0.04$ & $52.9 \pm 4.7$ & $54.1 \pm 4.7$ \\
\hline 4 & $0.67 \pm 0.02$ & $0.43 \pm 0.04$ & $63.2 \pm 2.3$ & $63.9 \pm 2.6$ \\
\hline 5 & $0.65 \pm 0.03$ & $0.33 \pm 0.06$ & $53.5 \pm 4.5$ & $51.0 \pm 3.2$ \\
\hline 6 & $0.66 \pm 0.04$ & $0.35 \pm 0.05$ & $54.5 \pm 3.1$ & $53.4 \pm 2.7$ \\
\hline 7 & $0.73 \pm 0.02$ & $0.50 \pm 0.03$ & $66.9 \pm 5.3$ & $68.3 \pm 2.1$ \\
\hline 8 & $0.68 \pm 0.03$ & $0.46 \pm 0.04$ & $70.9 \pm 8.6$ & $67.2 \pm 1.7$ \\
\hline 9 & $0.66 \pm 0.02$ & $0.33 \pm 0.03$ & $50.8 \pm 4.8$ & $50.0 \pm 3.9$ \\
\hline
\end{tabular}

\subsubsection{Analysis of Variance According to the Mixing Ratio}

To evaluate the cumulative methane yield and the VS removal rate in co-digestion of sewage sludge, food waste, and livestock manure, a multiple linear regression equation was applied to the results of nine BMP tests. The sparse linear equation was evaluated using analysis of variance (ANOVA), and a series of residual normal probability plots are described in Figure 4. The R program was used to model ANOVA, which is a nonparametric test that can be applied when the collected data show a skewed or biased non-normal distribution [26]. This technique allows the verification of whether there is a significant level of difference between the means in two or more groups [27]. This technique was applied because of the small amount of data obtained by performing the nine BMP tests. The relationship of the mixing ratio with the cumulative methane production is given in Equation (5), and the relationship of the mixing ratio with the VS removal rate is given in Equation (6).

Cumulative methane production $(\mathrm{mL} / \mathrm{g}-\mathrm{VS})=0.6672 X_{1}+3.5816 X_{2}+0.431 X_{3}+209.240$

$$
\text { VS removal }(\%)=0.0648 X_{1}+0.3991 X_{2}+0.0291 X_{3}+39.1760
$$

where $X_{1}$ is the mixing ratio of sewage sludge (\%), $X_{2}$ is the mixing ratio of food wastes $(\%)$, and $X_{3}$ is the mixing ratio of livestock manure (\%).

As shown in the multiple linear regression equations, food wastes had the highest weights in cumulative methane production and VS removal rate. The model was tested using the $p$-value. No null hypothesis was established if the $p$-value was smaller than 0.05 , and the model was judged to be significant [28]. The model fitness results for the cumulative methane production and VS removal rate are summarized in Table 7; the $p$-value was smaller than 0.05 , thereby indicating that no significant relationship was present [29]. The normal probability distribution was slightly different depending on the location, but it was properly fitted. The Normal Q-Q plot did not show an ideal form, but the model was reliable because the data were evenly distributed. As sewage sludge, food waste, and livestock manure showed positive values, cumulative methane production and the VS removal rate were found to have a synergistic effect during the co-digestion of these substrates (Tables 8-10). In particular, food waste showed a higher contribution, which was attributed to the high organic content of food waste compared with that of the other substrates. 


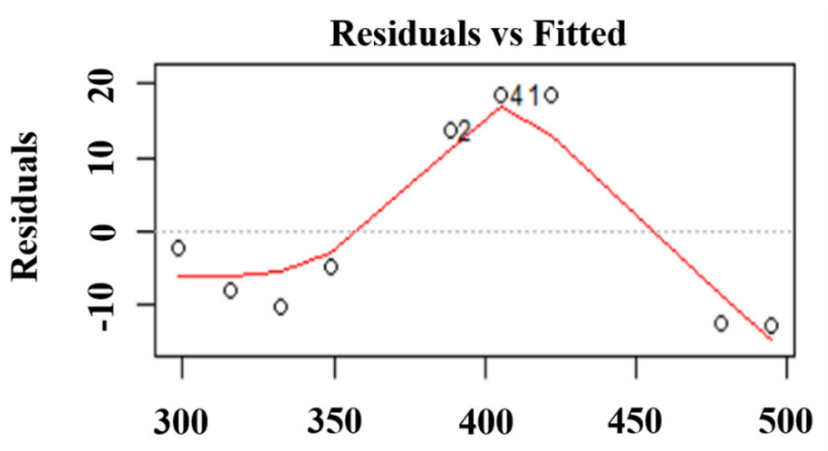

Fitted values

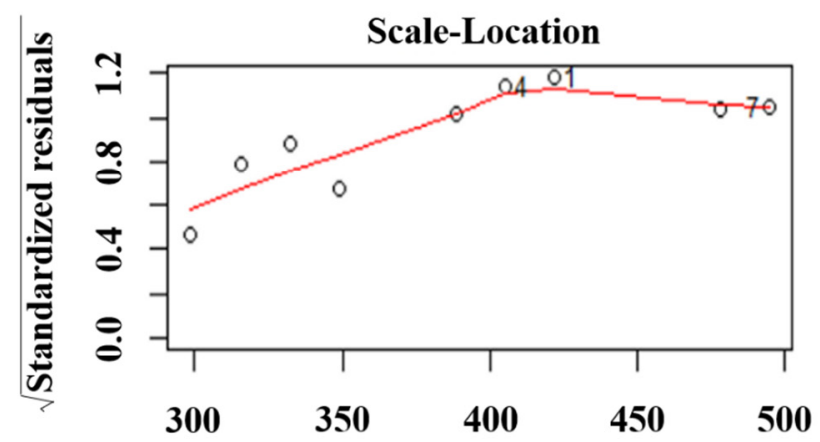

Fitted values

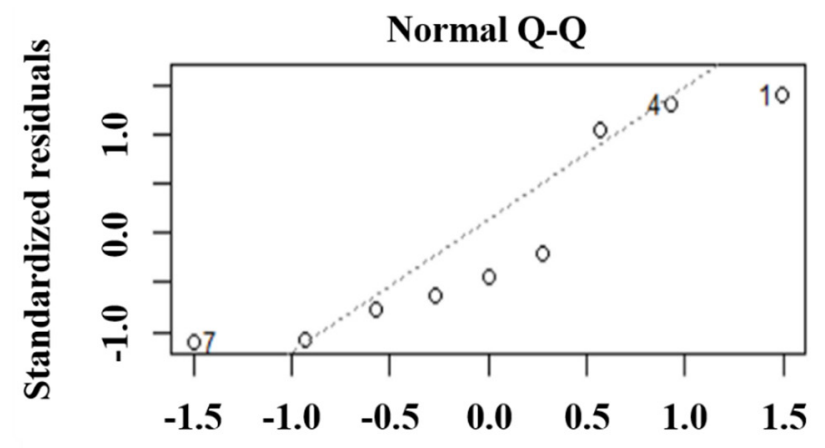

Theoretical Quantiles

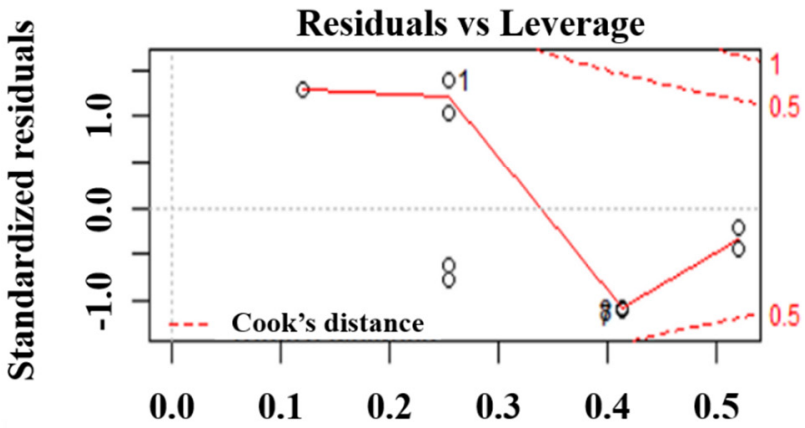

Leverage

Figure 4. Normal probability distribution for cumulative methane yield.

Table 7. Analysis of variance for cumulative methane production.

\begin{tabular}{cccccc}
\hline Source & DF & Seq SS & Mean Sq & $\boldsymbol{F}$ & $p$-Value \\
\hline Sewage sludge & 1 & 1135 & 1135 & 4.9 & 0.068 \\
\hline Food waste & 1 & 37582 & 37582 & 162.6 & $<0.050^{*}$ \\
\hline Livestock manure & 1 & 948 & 948 & 1.3 & 0.121 \\
\hline Residual error & 6 & 1387 & 231 & - & - \\
\hline Signif: $0.01:{ }^{*}$ & & & & &
\end{tabular}

Signif: 0.01: *.

Table 8. Cumulative methane production from multiple regression.

\begin{tabular}{|c|c|c|c|c|}
\hline Source & Estimate & Std. Error & $t$-Value & $p$-Value \\
\hline Intercept & 209.2400 & 1.7456 & 12.495 & $<0.050 * * *$ \\
\hline Sewage sludge & 0.6672 & 0.2220 & 3.005 & $0.024 *$ \\
\hline Food waste & 3.5816 & 0.2809 & 12.752 & $<0.050^{* * *}$ \\
\hline Livestock manure & 0.4310 & 0.2641 & 1.632 & $0.013 *$ \\
\hline \multicolumn{2}{|c|}{ Residual standard error } & \multicolumn{3}{|c|}{15.2 on 6 degrees of freedom } \\
\hline \multicolumn{2}{|c|}{ Multiple R-squared: } & \multicolumn{3}{|c|}{0.9654} \\
\hline \multicolumn{2}{|c|}{ Adjusted R-squared: } & \multicolumn{3}{|c|}{0.9539} \\
\hline \multicolumn{2}{|c|}{ F-statistic: } & \multicolumn{3}{|c|}{83.76 on 2 and $6 \mathrm{DF}$} \\
\hline \multicolumn{2}{|c|}{$p$-value } & \multicolumn{3}{|c|}{$<0.05^{* * *}$} \\
\hline
\end{tabular}


Table 9. Volatile solids (VS) removal rate from multiple regression.

\begin{tabular}{ccccc}
\hline Source & Estimate & Std. Error & $t$-Value & $p$-Value \\
\hline Intercept & 39.1760 & 2.7790 & 14.097 & $<0.050^{* * *}$ \\
\hline Sewage sludge & 0.0648 & 0.0369 & 1.758 & 0.129 \\
\hline Food waste & 0.3990 & 0.0466 & 8.561 & $<0.050^{* *}$ \\
\hline Livestock manure & 0.0291 & 0.0548 & 1.883 & 0.234 \\
\hline Residual standard error & \multicolumn{3}{c}{2.523 on 6 degrees of freedom } \\
\hline Multiple R-squared: & \multicolumn{3}{c}{0.9272} \\
\hline Adjusted R-squared: & \multicolumn{3}{c}{38.21 on 2 and 6 DF } \\
\hline F-statistic: & \multicolumn{3}{c}{$<0.05$ ** } \\
\hline p-value
\end{tabular}

Signif: $0:{ }^{* * *} ; 0.001:{ }^{* *}$.

Table 10. Analysis of variance for volatile solids (VS) removal.

\begin{tabular}{cccccc}
\hline Source & DF & Seq SS & Mean Sq & $\boldsymbol{F}$ & $p$-Value \\
\hline Sewage sludge & 1 & 19.90 & 19.90 & 3.13 & 0.127 \\
\hline Food waste & 1 & 466.50 & 466.50 & 73.30 & $<0.050^{*}$ \\
\hline Livestock manure & 1 & 17.20 & 17.20 & 2.48 & 0.154 \\
\hline Residual error & 6 & 38.19 & 6.37 & - & - \\
\hline Signif: $0.01:{ }^{*}$. & & & & &
\end{tabular}

\subsubsection{Derivation of the Optimal Mixing Ratio}

A higher proportion of food waste in the mixing ratio was more advantageous to maximize methane production during the co-digestion of sewage sludge, food waste, and livestock manure. However, it is necessary to derive an appropriate mixing ratio for organic waste production to enable stable operation at a high OLR. To derive the optimal mixing ratio, a simplex-centroid design was determined using Design Expert 10 (Stat Easy Co., Minneapolis, MN, USA). The total mixing ratio of each substrate was set to $100 \%$, and response surface analysis was performed for three dependent variables (VS removal rate, biodegradability, and methane yield). The mixing model was assumed by using the following formula, with the sum of the mixing ratio of sewage sludge, food waste, and livestock manure as $100 \%$ [30]:

$$
Y=\beta_{1} X_{1}+\beta_{2} X_{2}+\beta_{3} X_{3}+\beta_{12} X_{1} X_{2}+\beta_{13} X_{1} X_{3}+\beta_{23} X_{2} X_{3}+\beta_{123} X_{1} X_{2} X_{3}
$$

where $Y$ is the dependent variable; $X_{1}, X_{2}$, and $X_{3}$ are the independent variables; and $\beta_{1}$, $\beta_{2}, \beta_{3}, \beta_{12}, \beta_{13}, \beta_{23}$, and $\beta_{123}$ are the regression coefficients.

ANOVA was used to analyze the results of the BMP tests, and the mixing ratio for optimal methanogenesis was calculated using response surface methodology (RSM). RSM is an experimental design method used to investigate the relationship between one or more response variables and a set of quantitative experimental variables or factors. When optimal conditions are found using ANOVA, the relationship between input variables $X_{1}$, $\ldots$, and $X_{n}$ and the resultant values of $Y$ can be used to determine if curvature exists in the response variable. This is mainly used to determine the conditions of the factors that show the optimal response. Therefore, it is necessary to confirm the appropriate regime of the region of interest on the response surface [31]. A diagram was constructed based on the results in Tables 8 and 10 to input the amount of methane production as a response variable. In addition, the actual methane production and the equations from ANOVA can be combined to finally obtain the cumulative methane production according to the mixing ratio by inputting Equations (6) and (7), which are linear regression equations for cumulative methane production and VS removal rate, respectively, into the program. 
Consequently, maximizing the amount of methane production during the co-digestion of sewage sludge, food waste, and livestock manure is more advantageous with an increase in the proportion of food waste in the mixing ratio. The range showed a cumulative methane production of more than $300 \mathrm{~mL} \mathrm{CH}_{4} / \mathrm{g}$ VS when the content of food waste was set to $100 \%$. However, considering the method for increasing the methane production from sewage sludge, various mixing ratios could be determined within the range, which indicated a methane yield of 250-300 $\mathrm{mL} \mathrm{CH}_{4} / \mathrm{g} \mathrm{VS}$, as discussed in Section 4 [32]. Therefore, it is advantageous to set up a section in which the mixing ratio of sewage sludge is as high as possible. As a result, the optimal mixing ratio can be set to $50 \%$ sewage sludge, $25 \%$ food waste, and 25\% livestock manure (Figure 5).

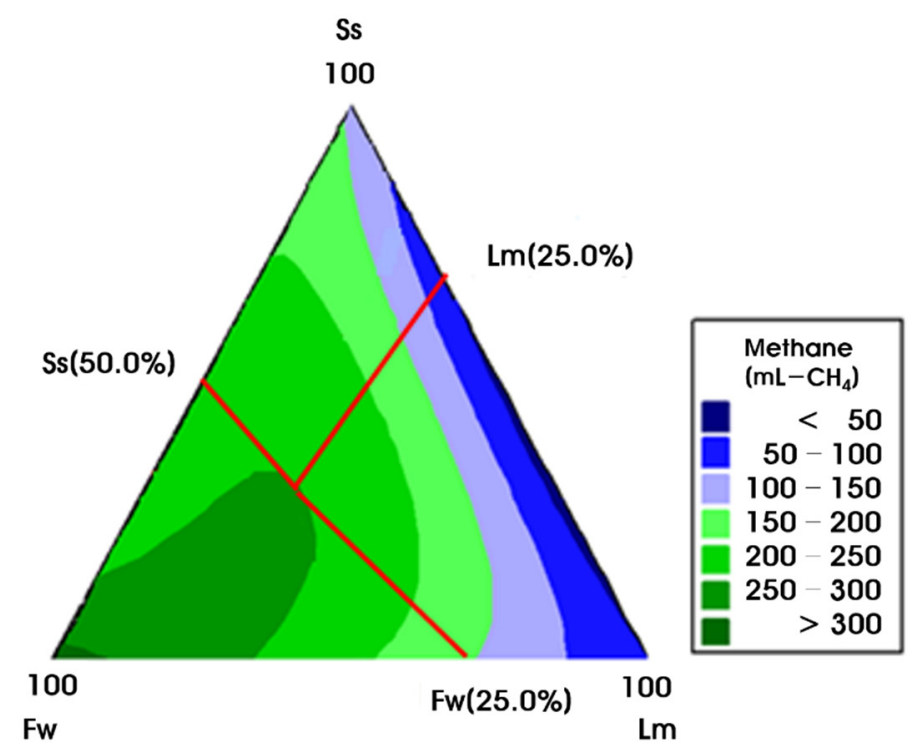

Figure 5. Determination of the optimal mixing ratio (Lm: Livestock manure; Ss: Sewage slduge; Fw: Food waste).

\section{Discussion}

Based on the physicochemical characteristics, biodegradability, and organic matter decomposition rates of the organic wastes determined using the BMP test method, the $\mathrm{pH}$ of livestock manure with a high ammonia content was found to be the highest whereas food waste had the lowest $\mathrm{pH}$ owing to pre-acidification [33]. The results of the theoretical methane yield based on the elemental composition according to each OLR indicated that the theoretical methane yield increased owing to the increasing carbon content as the OLR increased [34]. A previous study improved the methane yield by adding carbon to the $\mathrm{AD}$ reactor [35]. The researchers reported that methane yield was improved as the carbon addition increased within an optimal OLR range [35]. It was concluded that food waste can produce more methane than other substrates because of its high carbon content. In other words, the carbon content contributes not only to the improvement of the theoretical methane yield but also to the improvement of the actual methane yield. The sewage sludge tended to decrease after the occurrence of up to $334 \mathrm{~mL} \mathrm{CH}_{4} / \mathrm{g} \mathrm{VS}$ at $4 \mathrm{~kg}$ VS without an increase in the actual methane yield as the OLR increased, which was unlike the theoretical methane yield. The highest actual methane yield of food waste was observed at $6 \mathrm{~kg}$ VS with a value of $573 \mathrm{~mL} \mathrm{CH}_{4} / \mathrm{g}$ VS. The actual methane yield of livestock manure tended to decrease as the OLR increased. These results might have been driven by the carbon element and substrate characteristics. Food waste that has a high substrate utilization rate may be more biodegradable than sewage sludge and livestock manure, which are considered byproducts formed from microorganism metabolism [36]. The actual methane production of each substrate was similar to the biodegradability of sewage sludge, food waste, and livestock manure, which was 54.3\% (at $4 \mathrm{~kg}$ VS OLR), 
$77.0 \%$ (at $6 \mathrm{~kg}$ VS OLR), and 49.5\% (at $2 \mathrm{~kg}$ VS OLR), respectively. The optimal mixing ratio was derived using the CART technique to determine the optimal mixing ratio that satisfies the VS removal rate, biodegradability, and methane production rates of sewage sludge, food waste, and livestock manure [37]. A total of 16 cases were applied with proportions of $0 \%, 25 \%, 50 \%, 75 \%$, and $100 \%$ and a total of 9 cases (excluding $100 \%$ of each substrate and $0 \%$ of food waste) were analyzed. The BMP test results according to the nine mixing ratios from Runs 1 to 9 showed that the methane yields of Runs 7 and 8 were $482 \mathrm{~mL} \mathrm{CH}_{4} / \mathrm{g}$ VS and $465 \mathrm{~mL} \mathrm{CH}_{4} / \mathrm{g}$ VS, respectively. The highest cumulative methane production was found under a food waste mixing ratio of $75 \%$. However, the cumulative methane production was the lowest in Runs 3, 5, and 9, which showed methane yields of 342, 317, and $306 \mathrm{~mL} \mathrm{CH}_{4} / \mathrm{g}$ VS, respectively. The cumulative methane production and VS removal rates were found to have a synergistic effect. In particular, food waste was found to have the highest cumulative methane production and VS removal rate $(p<0.05)$. This study shows that the cumulative methane production rate can vary according to the mixing ratio of food waste with higher carbon content and VS removal rate than those of other substrates. Moreover, the cumulative methane production rate decreased as the mixing ratio of livestock manure increased compared with that of sewage sludge and even when the mixing ratio was the same. To obtain the optimal mixing ratio, the results of multiple linear regression and variance analyses were obtained using Design Expert 10 (Stat Easy Co., Minneapolis, MN, USA). The optimal methane production occurred at a mixing ratio of $50 \%$ sewage sludge, $25 \%$ food waste, and $25 \%$ livestock manure. The results of this study show that co-digestion can be operated fluidly by adjusting the mixing ratios of sewage sludge, food waste, and livestock manure. Moreover, a lower $\mathrm{pH}$ and alkalinity in food waste can be supplemented by livestock manure with a higher $\mathrm{pH}$ and alkalinity [38], and lower carbon content and biodegradability can be supported by food waste with higher carbon content and biodegradability $[35,39]$. These mutual supplementations can help to balance the reaction rates of each step by solving representative problems in the AD reactor, such as a low pH, lack of alkalinity, and the presence of toxic substances [35]. Therefore, co-digestion may be a realizable strategy for the improvement of biogas production and achievement of process stability when various substrates are mixed at optimal ratios $[38,40]$.

\section{Conclusions}

In this study, the optimal mixing ratio of organic wastes such as food waste and livestock manure were objectively derived using a statistical method to increase the efficiency of the AD of sewage sludge, and the optimal inlet OLR was calculated. As the load increased, the theoretical amount of methane production increased. Therefore, we concluded that food waste could generate more methane than other substrates. The actual amount of methane generated was the highest at $4 \mathrm{~kg}$ VS for sewage sludge, $6 \mathrm{~kg}$ VS for food waste, and $2 \mathrm{~kg}$ VS for livestock manure. Thus, the methane production characteristics and appropriate load for each substrate were confirmed. The BMP test results showed that the higher the mixing ratio of food waste, the higher the cumulative methane yield. Even in the formula developed via multiple linear regression analysis, it was found that food waste had the greatest weight $(p<0.05)$ in the cumulative methane yield and VS removal rate, and as the mixing ratio of livestock manure increased, the methane yield decreased. Multiple linear regression analysis and ANOVA were conducted using Design Expert 10 to determine the stable operation conditions for domestic organic wastes and high loads; the optimal mixing ratio was determined to be $50 \%$ sewage sludge, $25 \%$ food waste, and $25 \%$ livestock manure. Overall, co-digestion with an optimal mixing ratio reduces costs, such as transportation and treatment costs incurred for dumping sewage sludge in landfills and reduces related environmental problems. It is believed that greater amounts of energy can be recovered from the optimally mixed substrates, which can provide improved process stability, high energy efficiency, and a strategy for solving representative problems in common AD reactors. 
Author Contributions: Conceptualization, Y.-J.S., K.-S.O., B.L. and J.-G.P.; formal analysis, Y.-J.S., K.-S.O. and D.-W.P.; investigation, Y.-J.S. and B.L.; methodology, Y.-J.S., K.-S.O. and J.-G.P.; resources, K.-S.O. and B.L.; software, K.-S.O., J.-H.C. and J.-G.P.; validation, Y.-J.S., B.L. and D.-W.P.; writingoriginal draft, Y.-J.S., B.L., K.-S.O., D.-W.P., J.-H.C. and J.-G.P.; writing-review and editing, Y.-J.S., K.-S.O., B.L., D.-W.P. and J.-G.P. All authors have read and agreed to the published version of the manuscript.

Funding: This research was funded by Chosun University 2021, grant number K208702001, and by the Korea Ministry of Environment as a Waste to Energy-Recycling Human Resource Development Project, grant number YL-WE-19-001.

Institutional Review Board Statement: Not applicable.

Informed Consent Statement: Not applicable.

Data Availability Statement: Not applicable.

Conflicts of Interest: The authors declare no conflict of interest.

\section{References}

1. Bergesen, H.O.; Parmann, G.; Thommessen, Ø.B. Yearbook of International Cooperation on Environment and Development 1998-1999. Convention on the Prevention of Marine Pollution by Dumping of Wastes and Other Matter (London Convention 1972); Routledge: London, UK, 2018; pp. 98-100.

2. Farnelli, G.M.; Tanzi, A. Elgar Encyclopedia of Environmental Law. Convention on the Prevention of Marine Pollution by Dumping of Wastes and Other Matter 1972 and 1996 Protocol. Available online: https:/ /www.elgaronline.com/view/nlm-book/ 9781786436986/b-9781783477210-V_16.xml (accessed on 11 October 2021).

3. Atelge, M.R.; Krisa, D.; Kumar, G.; Eskicioglu, C.; Nguyen, D.D.; Chang, S.W.; Atabani, A.E.; Al-Muhtaseb, A.H.; Unalan, S. Biogas production from organic waste: Recent progress and perspectives. Waste Biomass Valoriz. 2020, 11, 1019-1040. [CrossRef]

4. Park, J.G.; Jiang, D.; Lee, B.; Jun, H.B. Towards the practical application of bioelectrochemical anaerobic digestion (BEAD): Insights into electrode materials, reactor configurations, and process designs. Water Res. 2020, 184, 116214. [CrossRef]

5. Kaur, G.; Luo, L.; Chen, G.; Wong, J.W. Integrated food waste and sewage treatment-A better approach than conventional food waste-sludge co-digestion for higher energy recovery via anaerobic digestion. Bioresour. Technol. 2019, 289, 121698. [CrossRef]

6. Park, J.; Lee, B.; Tian, D.; Jun, H. Bioelectrochemical enhancement of methane production from highly concentrated food waste in a combined anaerobic digester and microbial electrolysis cell. Bioresour. Technol. 2018, 247, 226-233. [CrossRef]

7. Nguyen, V.K.; Chaudhary, D.K.; Dahal, R.H.; Trinh, N.H.; Kim, J.; Chang, S.W.; Nguyen, D.D. Review on pretreatment techniques to improve anaerobic digestion of sewage sludge. Fuel 2021, 285, 119105. [CrossRef]

8. Siddique, M.N.I.; Wahid, Z.A. Achievements and perspectives of anaerobic co-digestion: A review. J. Clean. Prod. 2018, 194, 359-371. [CrossRef]

9. Lu, D.; Xiao, K.; Chen, Y.; Soh, Y.N.A.; Zhou, Y. Transformation of dissolved organic matters produced from alkaline-ultrasonic sludge pretreatment in anaerobic digestion: From macro to micro. Water Res. 2018, 142, 138-146. [CrossRef] [PubMed]

10. Hong, E.H.; Park, J.G.; Lee, B.; Shi, W.Q.; Jun, H.B. Improvement of waste dehydrated sludge for anaerobic digestion through high-temperature and high-pressure solubilization. Energies 2020, 13, 88. [CrossRef]

11. Owen, W.P.; Stuckey, D.C.; Healy, J.B.; Young, L.T.; McCarty, P.L. Bioassay for monitoring biochemical methane potential and anaerobic toxicity. Water Res. 1979, 13, 485-492. [CrossRef]

12. Barker, H.; Buswell, A.M. Biological formation of methane. Ind. Eng. Chem. 1956, 48, 1438-1443. [CrossRef]

13. Akbas, H.; Ozdemir, G. Prediction modeling of biogas production with classification and regression tree at wastewater treatment plants. Eurasia Proc. Sci. Technol. Eng. Math. 2018, 4, 212-217.

14. Gunes, B.; Carrié, M.; Benyounis, K.; Stokes, J.; Davis, P.; Connolly, C.; Lawler, J. Optimisation and modelling of anaerobic digestion of whiskey distillery/brewery wastes after combined chemical and mechanical pre-treatment. Processes 2020, 8, 492. [CrossRef]

15. Eaton, A.D.; Clesceri, L.S.; Greenberg, A.E. Standard Methods for the Examination of Water and Wastewater, 19th ed.; Franson, M.A.H., Ed.; American Public Health Association: Washington, DC, USA, 1995.

16. Gonzalez, A.; Hendriks, A.T.W.M.; Van Lier, J.B.; De Kreuk, M. Pre-treatments to enhance the biodegradability of waste activated sludge: Elucidating the rate limiting step. Biotechnol. Adv. 2018, 36, 1434-1469. [CrossRef] [PubMed]

17. Mamimin, C.; Chanthong, S.; Leamdum, C.; Sompong, O.; Prasertsan, P. Improvement of empty palm fruit bunches biodegradability and biogas production by integrating the straw mushroom cultivation as a pretreatment in the solid-state anaerobic digestion. Bioresour. Technol. 2021, 319, 124227. [CrossRef]

18. Camargo, F.P.; Sakamoto, I.K.; Duarte, I.C.S.; Varesche, M.B.A. Influence of alkaline peroxide assisted and hydrothermal pretreatment on biodegradability and bio-hydrogen formation from citrus peel waste. Int. J. Hydrogen Energy 2019, 44, 2288822903. [CrossRef] 
19. Park, J.G.; Lee, B.; Jo, S.Y.; Lee, J.S.; Jun, H.B. Control of accumulated volatile fatty acids by recycling nitrified effluent. J. Environ. Health Sci. Eng. 2018, 16, 19-25. [CrossRef] [PubMed]

20. Nguyen, D.; Wu, Z.; Shrestha, S.; Lee, P.H.; Raskin, L.; Khanal, S.K. Intermittent micro-aeration: New strategy to control volatile fatty acid accumulation in high organic loading anaerobic digestion. Water Res. 2019, 166, 115080. [CrossRef] [PubMed]

21. Rabii, A.; Aldin, S.; Dahman, Y.; Elbeshbishy, E. A review on anaerobic co-digestion with a focus on the microbial populations and the effect of multi-stage digester configuration. Energies 2019, 12, 1106. [CrossRef]

22. Bayard, R.; Benbelkacem, H.; Gourdon, R.; Buffière, P. Characterization of selected municipal solid waste components to estimate their biodegradability. J. Environ. Manag. 2018, 216, 4-12. [CrossRef] [PubMed]

23. Astivia, O.L.O.; Zumbo, B.D. Heteroskedasticity in multiple regression analysis: What it is, how to detect it and how to solve it with applications in R and SPSS. Pract. Assess. Res. Eval. 2019, 24, 1. [CrossRef]

24. Gunes, B.; Stokes, J.; Davis, P.; Connolly, C.; Lawler, J. Optimisation of anaerobic digestion of pot ale after thermochemical pre-treatment through Response Surface Methodology. Biomass Bioenergy 2021, 144, 105902. [CrossRef]

25. Ren, Y.; Yu, M.; Wu, C.; Wang, Q.; Gao, M.; Huang, Q.; Liu, Y. A comprehensive review on food waste anaerobic digestion: Research updates and tendencies. Bioresour. Technol. 2018, 247, 1069-1076. [CrossRef] [PubMed]

26. Susanto, A.; Purwantini, D.; Santosa, S.A.; Candrasari, D.P. Pengaruh rasio induk: Pejantan terhadap taksiran heritabilitas menggunakan animal model reml dan anova. In Prosiding Seminar Teknologi Agribisnis Peternakan (stap) Fakultas Peternakan Universitas Jenderal Soedirman; Jenderal Soedirman University: Purwokerto, Indonesia, 2021; Volume 8, pp. 156-162.

27. Chambers, J.M.; Freeny, A.E.; Heiberger, R.M. Analysis of variance; Designed experiments. In Statistical Models in S; Routledge: London, UK, 2017; pp. 145-193.

28. Held, L.; Pawel, S. Comment on "The Role of p-Values in Judging the Strength of Evidence and Realistic Replication Expectations". Stat. Biopharm. Res. 2020, 13, 46-48. [CrossRef]

29. Betensky, R.A. The p-value requires context, not a threshold. Am. Stat. 2019, 73, 115-117. [CrossRef]

30. Jiao, D.; Shi, C.; Yuan, Q.; An, X.; Liu, Y. Mixture design of concrete using simplex centroid design method. Cem. Concr. Compos. 2018, 89, 76-88. [CrossRef]

31. Kainthola, J.; Kalamdhad, A.S.; Goud, V.V. Optimization of methane production during anaerobic co-digestion of rice straw and Hydrilla verticillata using response surface methodology. Fuel 2019, 235, 92-99. [CrossRef]

32. Sung, T.; Kim, S.; Kim, K.C. Thermoeconomic analysis of a biogas-fueled micro-gas turbine with a bottoming organic Rankine cycle for a sewage sludge and food waste treatment plant in the Republic of Korea. Appl. Therm. Eng. 2017, 127, 963-974. [CrossRef]

33. Yu, M.; Gao, M.; Wang, L.; Ren, Y.; Wu, C.; Ma, H.; Wang, Q. Kinetic modelling and synergistic impact evaluation for the anaerobic co-digestion of distillers' grains and food waste by ethanol pre-fermentation. Environ. Sci. Pollut. Res. 2018, 25, 30281-30291. [CrossRef]

34. Hao, H.T.N.; Karthikeyan, O.P.; Heimann, K. Bio-refining of carbohydrate-rich food waste for biofuels. Energies 2015, 8, 6350-6364. [CrossRef]

35. Mpofu, A.B.; Kibangou, V.A.; Kaira, W.M.; Oyekola, O.O.; Welz, P.J. Anaerobic Co-Digestion of Tannery and Slaughterhouse Wastewater for Solids Reduction and Resource Recovery: Effect of Sulfate Concentration and Inoculum to Substrate Ratio. Energies 2021, 14, 2491. [CrossRef]

36. Salehiyoun, A.R.; Di Maria, F.; Sharifi, M.; Norouzi, O.; Zilouei, H.; Aghbashlo, M. Anaerobic co-digestion of sewage sludge and slaughterhouse waste in existing wastewater digesters. Renew Energy 2020, 145, 2503-2509. [CrossRef]

37. Ruggero, F.; Gori, R.; Lubello, C. Methodologies to assess biodegradation of bioplastics during aerobic composting and anaerobic digestion: A review. Waste Manag. Res. 2019, 37, 959-975. [CrossRef] [PubMed]

38. Amha, Y.M.; Anwar, M.Z.; Brower, A.; Jacobsen, C.S.; Stadler, L.B.; Webster, T.M.; Smith, A.L. Inhibition of anaerobic digestion processes: Applications of molecular tools. Bioresour. Technol. 2018, 247, 999-1014. [CrossRef] [PubMed]

39. Shi, L.; Simplicio, W.S.; Wu, G.; Hu, Z.; Hu, H.; Zhan, X. Nutrient recovery from digestate of anaerobic digestion of livestock manure: A review. Curr. Pollut. Rep. 2018, 4, 74-83. [CrossRef]

40. Lee, J.; Shin, S.G.; Jang, H.M.; Kim, Y.B.; Lee, J.; Kim, Y.M. Characterization of antibiotic resistance genes in representative organic solid wastes: Food waste-recycling wastewater, manure, and sewage sludge. Sci. Total Environ. 2017, 579, 1692-1698. [CrossRef] 